\title{
THE DEATH OF IMMORTALITY
}

\author{
Life lessons.
}

BY KYLE L. WILSON \& ANDREW B. BARBOUR

C)

n all my years, I've never ..." the doctor trembled while checking the readings. "Your son, he's going to die."

Tears streamed down the mother's face. She gripped her newborn tightly. "What does that mean, he's going to die? How, how long does that take?"

The doctor hesitated. "Maybe a century. The genetic implants did not take. Somehow, the testing failed." Pulling up a millennium-old document in the Venter Laboratories database, he found the passage. "Continually shrinking telomeres. He will age and develop archaic tumours and, eventually, cancer. His body will fail. We haven't seen anything like this since the Mortal Era."

Jaw clenched, she chewed on her words. "Do you know how many centuries it took to get approval for a child? And now what ... he's like... like one of our dogs!"

Rosalind had followed the child since he first left his arcology six months ago. For much of Michael's journey, they were not alone. The world watched, captivated by the mortal's decision to leave his risk-free home. Rosalind, motivated by desire for advancement in a stagnant workforce, filmed his trek.

"Michael grew a grey hair. He's so different! The fans will go crazy when they see. And our updated 'road map', as he terms it, shows that we will lose communication for weeks. He wants to climb some mountain in a place called the Himalayas. And after that, Europe!"

Her boss was baffled. "You mean Europa? Surely he'd want to visit the moons..."

"No, Europe. Sir, I don't understand him."

"Who wants to go to that dreadful place? Since the floods it's been deserted. This story is great Rosy, can you figure out the mindset of the last person that will ever die?"

"He says it's to connect with his roots, to experience history. But I think he's insane. This is becoming too much for me. I need to be transferred."

"That's impossible, Rosy. No one else will risk leaving the arcologies. We need your reports for our ratings. Keep this up and I'll promote you within a century."

Despite her years, the reporter maintained a youthful complexion with rose-red cheeks and blonde hair. Next to her, the grey-haired

and sun-baked man. The stunning 400-yearold girl and ancient 90-year-old man traversed the sands of the old-world desert.

He grinned like a mad Cheshire at the sight of the dunes. "The Arabian desert.

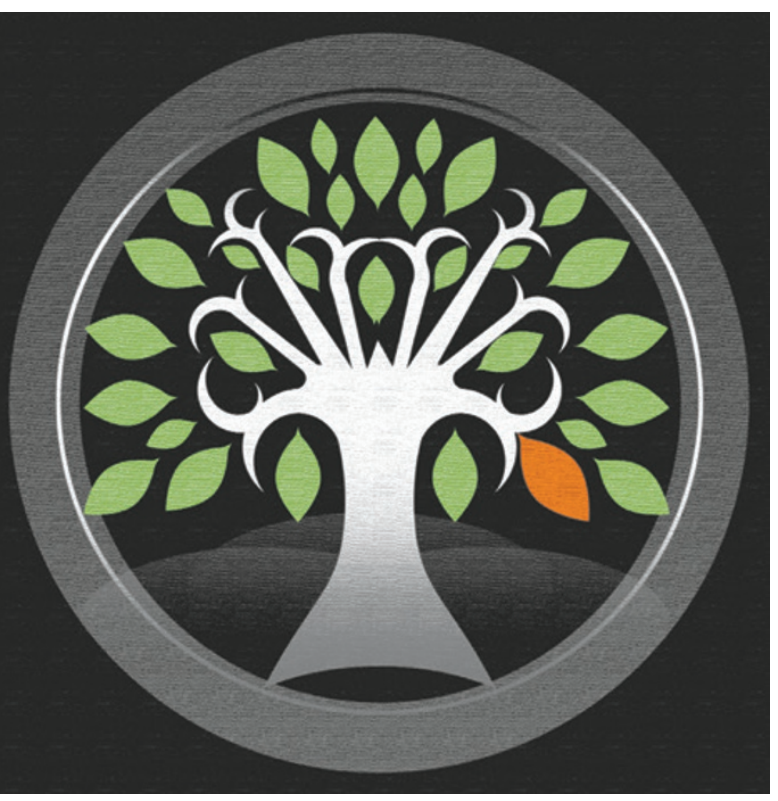

Where Lawrence fought all those years ago."

She smiled warmly with youthful radiance, comforted by the decades-long bond the pair had formed. "I never knew such a place existed. Michael, it’s stunning!" She was rather hot and needed some water. To her left, off in the distance, she noticed a snake slithering away. Impossible a thing could survive here.

They camped under the Milky Way's glow. She worked up a fire, a skill learned from Michael years ago. Hundreds of years and I had never made a fire before...

Suddenly, Michael started to cough. His once-strong legs shook as they strained to hold him upright. "Rose, I'm feeling weak now. The weakest since I left the hospital." He sounded worried, despite his typical confidence.

She was worried as well. She didn't know how to act around a dying man, no one did. "Michael, why don't we head back to the city -"

A crackling voice interrupted. "Where are you?! No updates in three months! We need

$\rightarrow$ NATURE.COM

Follow Futures: y @NatureFutures

$f$ go.nature.com/mtoodm a new report, we can only show so much old footage before people lose interest."

She maintained her composure while concerned for her dying friend. "It's not important now, Sir. I've been recording our observations and I'll submit them when we head back to the city." Abruptly, she turned off her communicator.

"Michael, let's go back. It's been walk walk walk for decades. You're fatigued." The white lie made her sad. What else could she say? Only he knew how to feel - after all, he'd spent years reading antiquated books on religion and death.

Back in the city hospital, Michael slipped away while Rosalind desperately gripped his hand. Really, the whole world held him. His death was broadcast live across the entire system, from Earth to Ganymede. Just like the doctor said: "Old age."

The audience watched his last breath. They didn't know what to make of it, wondering where he would go. Distressed and feeling that lingering existential dread, the world switched channels.

"Welcome to the Records and Application office, how may we serve you ... Oh! Rosalind! I loved your work on Michael."

Rose exchanged pleasantries before asking for the necessary forms. "I would like to apply for a child."

Held lightly in her hand, the pen danced across the tedious application. Upon review, she heard the administrator chuckle while flipping through her forms.

"A girl huh? That's great, I'm sure she will be just as adventurous as her mother!" The man read on. "Oh, uh... I see you've filled out the liability waiver to decline genetic implants. Funny, that's the fourth time I've seen that this week." His pen darted a note. "Well, the application is in order, but I'm required by law to advise you against this choice. After all, you know better than anyone the severe disability your child will face." Rosalind, warmly remembering her last days with Michael, nodded in acknowledgement.

Kyle L. Wilson is a PhD student at the University of Calgary, where he studies ecology and evolutionary biology. Andrew B. Barbour graduated with a PhD in fisheries from the University of Florida and now works as a research associate in neonatology at the Medical University of South Carolina. 